Physical Geography; Cartography; Geographic Information Systems \& Spatial Planing

\title{
SUITABILITY ANALYSIS FOR BUILDING DAM LAKES IN THE ORIENTAL CARPATHIAN MOUNTAINS, ROMANIA. CASE STUDY: TROTUS RIVER BASIN
}

DOI: http://dx.doi.org/10.18509/GBP.2016.14

UDC: 556.54:627.8.05(498)

\section{PhD Student Andrei Enea \\ MSc Student Daniel Neamțu \\ Conf. PhD.Cristian Constantin Stoleriu \\ Prof. PhD. Gheorghe Romanescu}

Alexandru Ioan Cuza University of Iași, Faculty of Geography and Geology, Department of Geography, Bd. Carol I 20A, 700505, Iasi, Romania

\begin{abstract}
This paper aims to analyze the suitability of Trotus river drainage basin, for building dam lakes. At present, water demand is a rising, global issue. There are numerous studies concerning water supply in different regions, as well as solutions for areas associated with water level decrease. Numerous economical sectors imply the use of water (agriculture, industry, tourism, food industry etc), therefore the analysis of areas where potential, new, artificial dam lakes can be built, is mandatory. There are numerous factors that engineers have to take into consideration, when building a dam for an artificial lake. Some of the most important parameters are land use, geology, soil and inhabited areas. For this study, these parameters have been combined into a multi-layer based GIS analysis, in which each layer has different values corresponding to the suitability of the elements contained on that layer, to the dam building purpose. The main results reveal a classified version of a suitability report, depicting the best areas for building a dam lake, in Trotus drainage basin. After choosing the best location for a potential, new lake, several calculations have been made, regarding simulated lake surface, the time it would take to fill the lake, according to different flow rates of the chosen river, the number of households that would have to be moved / relocated because of the lake expansion, and also potential estimated costs for the household relocation process. Overall, this methodological approach is considered to be valid, taking into consideration the validation of the results, with real life dams, that have already been built in these areas.
\end{abstract}

Keywords: dam lake, model, multi parameter, suitability

\section{INTRODUCTION AND STUDY AREA}

The human society has long required water for its various activities and evolution. Aside from the demographic boom, the need for water also originates from the strong industrialization tendency which characterized the last 200 years. In the present day, the greatest water consumers are the agriculture and the heavy industry.

These necessities are partly accounted for through the development of anthropic reservoirs resulted from the blocking the water courses. Another solution involves accessing and utilizing the ground water reserves. Although most of the times, the quality of the ground water is high, its extraction process is more expensive and it has the capacity 
to affect the phreatic level with undesirable consequences. Accumulating water into anthropic reservoirs also has its problems, which can appear during the service time of the dam, noteworthy being: lower quality of the water due to polluting of the tributary water courses, considerably large space required for such endeavors, creating imbalance into or even destruction of some ecosystems through flooding, altering the reproduction ability of the local ichthyofauna by impairing its ability to advance upstream; the potential failure of the dam and subsequent flooding of the downstream areas, landslides which may occur due to the induced seepage; as well as after the end of the service time of the dam: maintenance and cleaning costs, land use after the decommissioning of the dam, etc. However, the construction of a dam and the birth of its respective reservoir also has great advantages, the main one being the possibility to use the water as a resource for multiple purposes: generating green electric energy, with a very low carbon footprint, regulating of a water course by flow control, protecting the downstream areas from potential floods [1], fish farming, using the water for irrigations, as well as for recreational activities and sport, and many more. For the current study area, there were several studies [2].

The purpose of this paper is to use GIS techniques in order to create a model which can assess the land according to an array of selected parameters and quantify the areas which are considered as suitable locations for the construction of a dam (and respective reservoir), within the Trotus River basin (Fig. 1). After developing the suitability map for reservoir locations, one site is selected and the development of a dam reservoir is simulated. Additionally, the approach also aims at determining certain morphometric indices, which are considered relevant to the selected site, in order to correlate them with the characteristics of the reservoir.

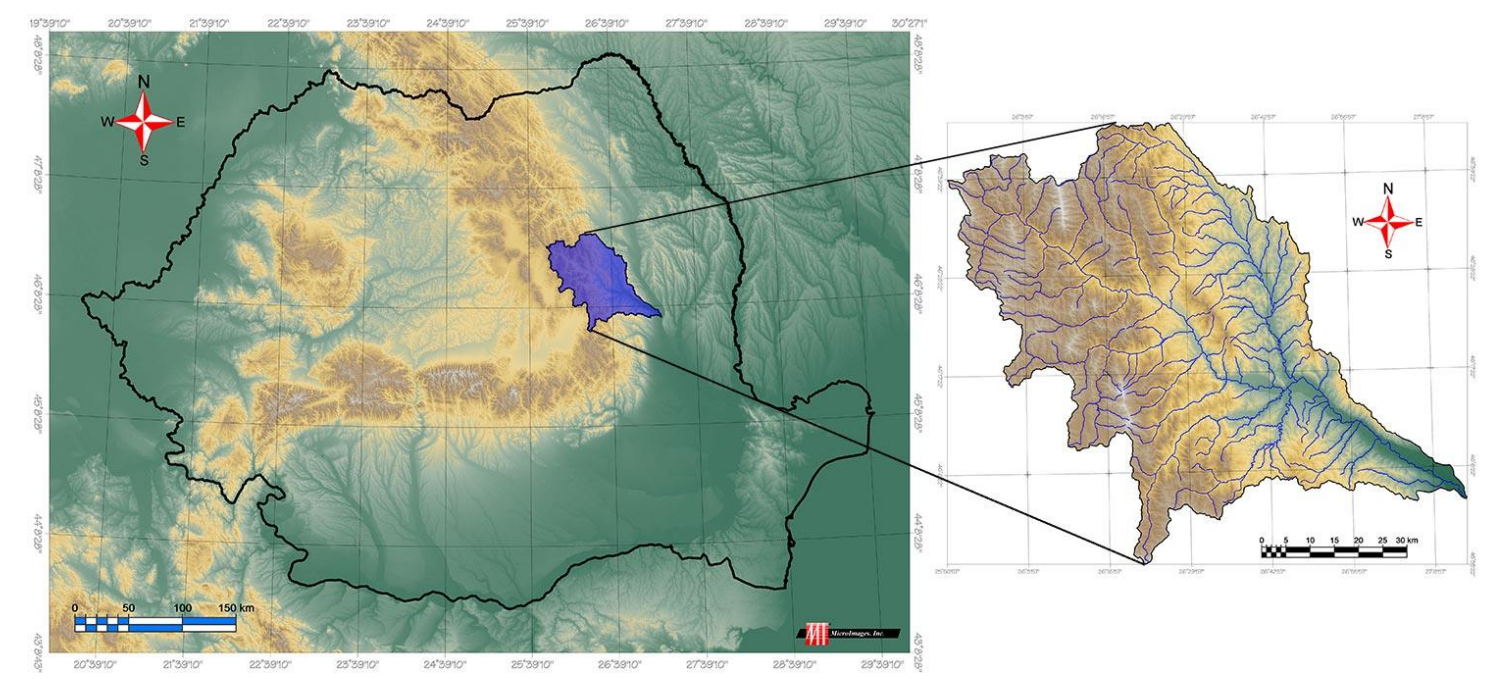

Figure 1. - Geographical location of the study area

\section{METHODOLOGY}

The proposed line of work entailed several stages (Fig. 2), involving both analogue and digital data. The analogue data was comprised of topographical, pedological and geological maps, at various scales. Therefore, 1:25000 topographical sheets (1982) were obtained, then scanned and imported into a GIS medium, and later on, georeferenced. The first geospatial element to be determined was the watershed divide of the Trotus River basin, through manual digitization, which constituted the basis upon which the subsequent geospatial layers were extracted. Considering the great surface of the basin, 
the chosen elevation model was the SRTM (80x80m cell resolution). Using the elevation model and applying a SML ${ }^{1}$, the slope was derived, and classified into geomorphologically determined classes. The SRTM was used for generating all the subsequent rasters, for the basin, in order to maintain the same cell resolution and alignment, which would permit the overlaying of the rasters through the use of a geoformula.

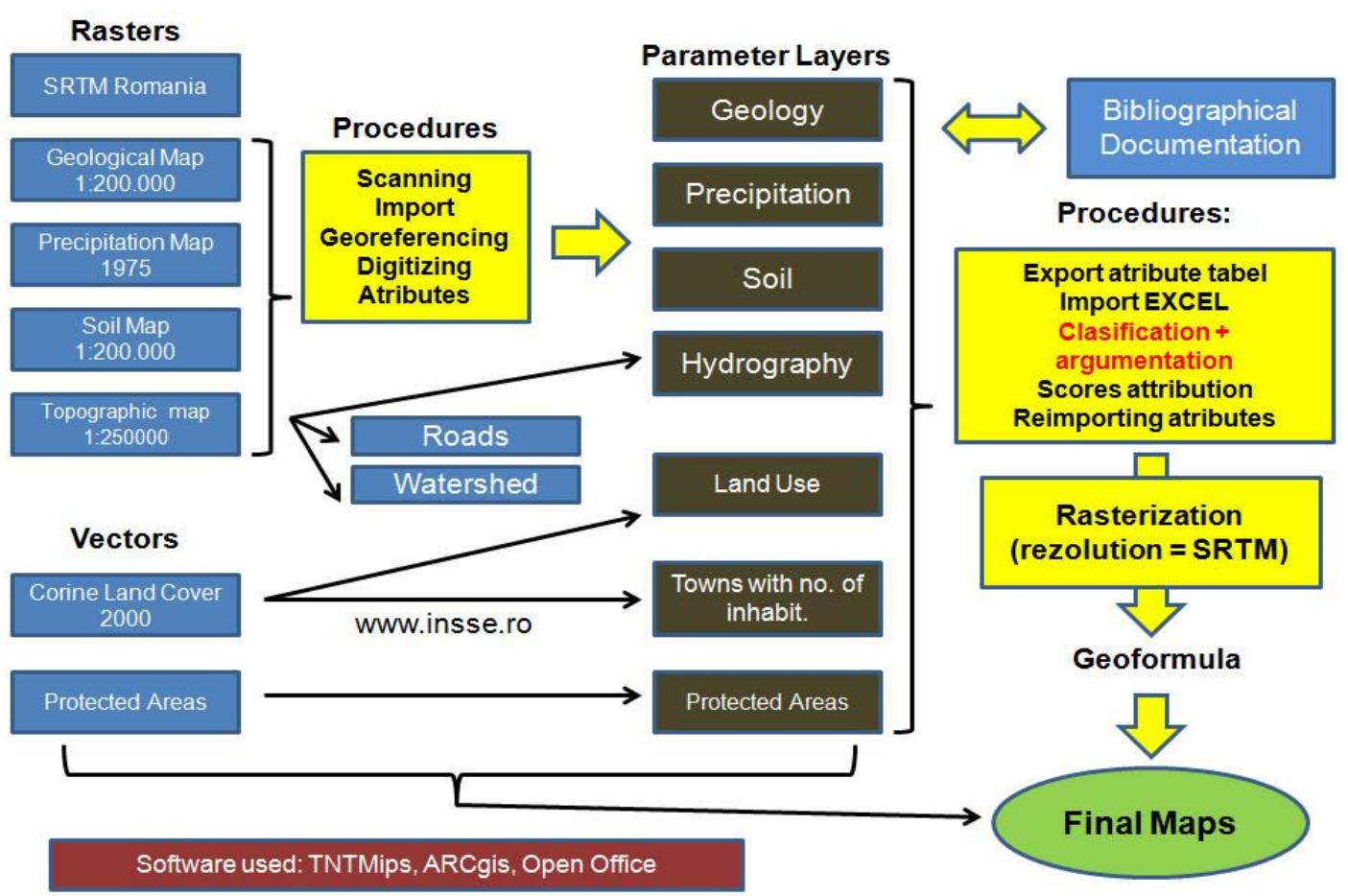

Figure 2. The general methodology applied in the suitability analysis

Additionally, the CLC $2000^{2}$ geospatial layer was used, in order to determine the boundary of the residential areas within the population parameter, used further on in determining the best settlement to house such a hydrotechnical construction. Using the vector files provided by the Ministry of the Environment, and from the Natura2000 website, a protected areas layer was able to be introduced in the analysis.

\section{Geology layer}

Having information about the underlying geology is of foremost importance when selecting a place to construct a dam. In such cases, the geological strata must fulfil certain criteria: increased impermeability to water, monolithic character, with no cracks or faults, because of to the inherent seismic risk. Also, the geological strata must emphasize low elasticity and increased resistance. The Trotus river basin is comprised of sandstone deposits, sandstone flysch, with some recent alluvial deposits (Neogene, Cuaternary), containing sand, conglomerates, breccia, shale and loam. According to their characteristics, the geological strata was ranked in a binary score system ( 1 or 0$)$, where 1 indicates suitable conditions for dam building, and 0 unsuitable conditions.

\footnotetext{
${ }^{1} \mathrm{SML}=$ Spatial Manipulation Language (used for classifying raster files)

${ }^{2} \mathrm{Geospatial}=$ http://earth.unibuc.ro/download/datele-corine-landcover-reproiectate-in-stereo70
} 


\section{Land use layer}

The land use is of lower importance to the determining aspects of the potential location of a reservoir; however, it is correlated with the costs of the project. To this end, by analyzing the CLC layer, the cost of the flooding area can be classified hierarchically. In other words, the area which needs to be flooded once the dam is build, belongs to many property owners, and it can be ranked as such, that the feasibility of the construction of the dam accounts for the economical aspect, in the eventuality of the need for potential compensation actions.

Values ranging from 0 to 100 were granted, and the main determining factor was of economic nature, 0 representing areas with high compensation costs (industrial establishments, transportation networks, urban areas, etc.), and 100 representing areas where the compensation costs would be minimal or inexistent (rocky areas, pastures, meadows, etc.).

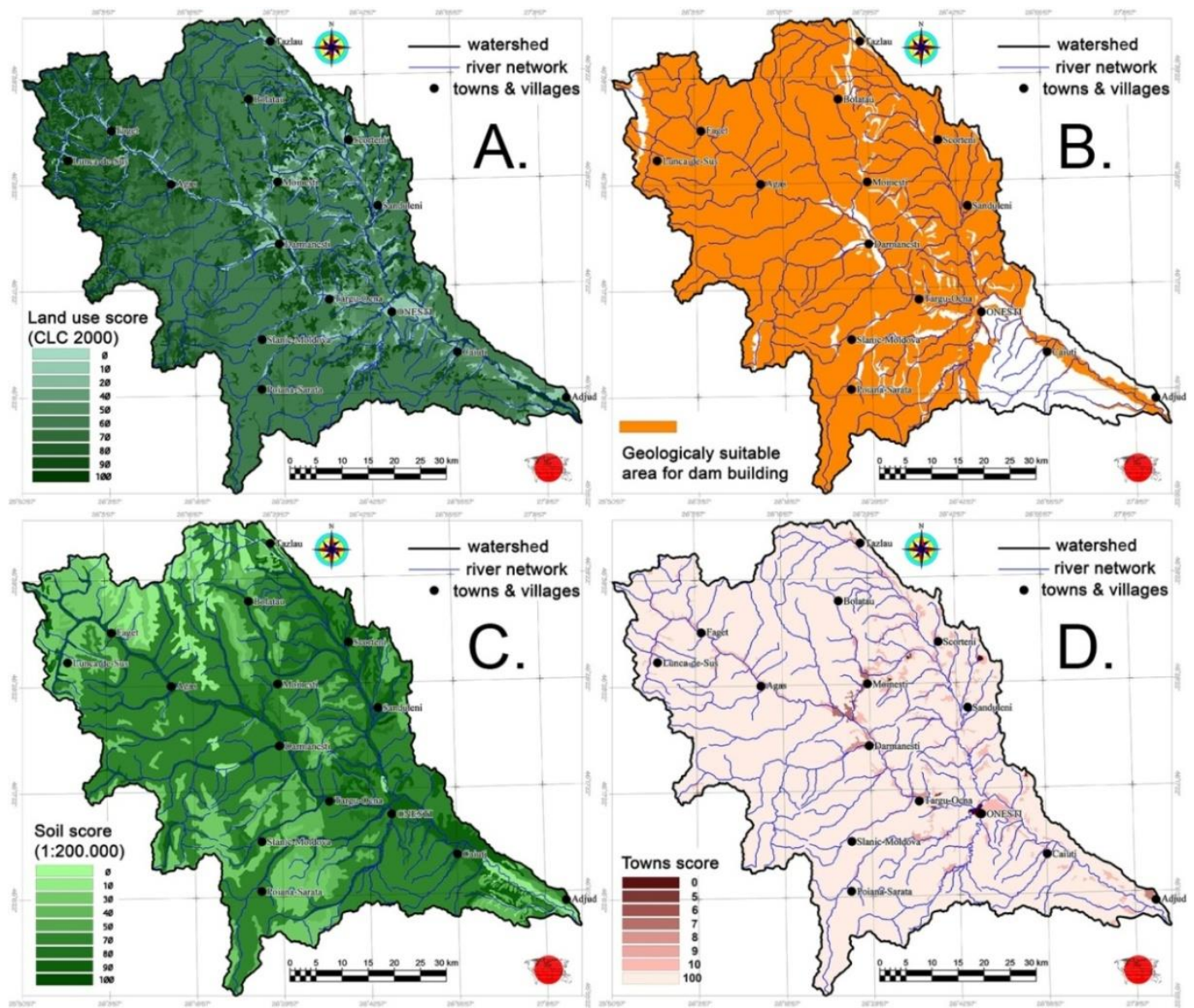

Figure 3. Parameters used in the suitability analysis for building dam lakes

\section{Population layer}

This parameter represents qualitative data concerning the number of inhabitants in the human settlements contained within the study area. The demographic density can be calculated. Apparently of low importance, it does have useful applications. This subject was thoroughly studied by Gheorghe, (2004) and Unguras, $(2011)[3,4]$. The area flooded by a dam reservoir varies from just a few hectares, to several hundred square kilometers. However, if a small area has a great population density, the relocation costs can be very large. Depending on the number of inhabitants, each settlement was ranked with values 
from 0 to 100 , where 0 stands for the areas with the greatest population densities (unsuitable for the location of a reservoir) and 100 for the areas with no human settlements. According to the 1996 census, in the Trotus River basin, there are 204 human settlements, totaling 342750 inhabitants. The average density is 76.9 inhabitants per square kilometer. However, the majority of the population is concentrated in the perimeter of 6 localities: Onesti, Moinesti, Comanesti, Adjud, TarguOcna and Darmanesti, each having over 10000 inhabitants. Therefore, a great part of the population is concentrated over a relatively small area.

\section{Soil layer}

Analyzing the soils prior to the deployment of the construction procedures for the dam itself is imperious, as it can prevent many problems, such as silting of the lacustrine cuvette, the soil texture together with the vegetation having an important role in the ampleness of the phenomenon. The soils were ranked using values from 0 to 100 , according to their texture. Therefore, skeletic, unconsolidated soils, with high particle size receive low values, and loamy soils, with very fine particle size receive high values. The values are directly linked to the water impermeability and soil stability.

\section{Natural reserves layer}

There are 6 protected areas in the Trotus River basin (Table 1), totaling 1152 hectares. Compared with the total area of the basin, the protected areas occupy only $0.25 \%$ of it. However it is very important to mention them because any anthropic intervention within their perimeter is forbidden by law. Therefore, any activity which influences the environmental conditions from these areas should be limited to caretaking and monitoring procedures carried out in such areas.

Table 1. Natural reserves located in the study area

\begin{tabular}{lcc}
\multicolumn{1}{c}{ Name of natural reservation } & Surface (ha) & County \\
Dealul Perchiu & 189 & Bacau \\
Magura - Tg. Ocna & 124.4 & Bacau \\
Padurea Izvorul Alb & 22.8 & Bacau \\
Rezervatia faunistica Brates & 30.6 & Neamt \\
Rezervatia naturala Bucias & 683.9 & Bacau \\
Tinovul de la Plaiesii de Jos & 101.4 & Harghita
\end{tabular}

\section{RESULTS AND DISCUSSION}

As a final step, using the aforementioned parameters, the suitability map for dam reservoir locations was created (Fig. 4). The shades of red and yellow signify the lack of the necessary conditions for such a construction, whereas the shades of green mark the presence of suitable conditions.

In the south-eastern side of the basin, the suitability is low mainly because of the characteristics of the geological strata. The part of the Carphatian range overlapping the basin, has the less suitable areas, less represented when compared to the situation at the confluence of the Trotus river to the Siret river, the first unsuitable area being located in the Darmanesti depression, as a consequence of the high population density found there; the second unsuitable area being located in the extreme west of the basin, inheriting its negative characteristic from the underlying geological strata. Within the study basin, many areas which could be the location of a reservoir dam were identified. Most of these are located on the mountainous tributaries of the Trotus river, as creating a dam on its 
main valley being very improbable, due to the very high population density in these areas (deploying such a project would lead to the re-location of thousands of people).

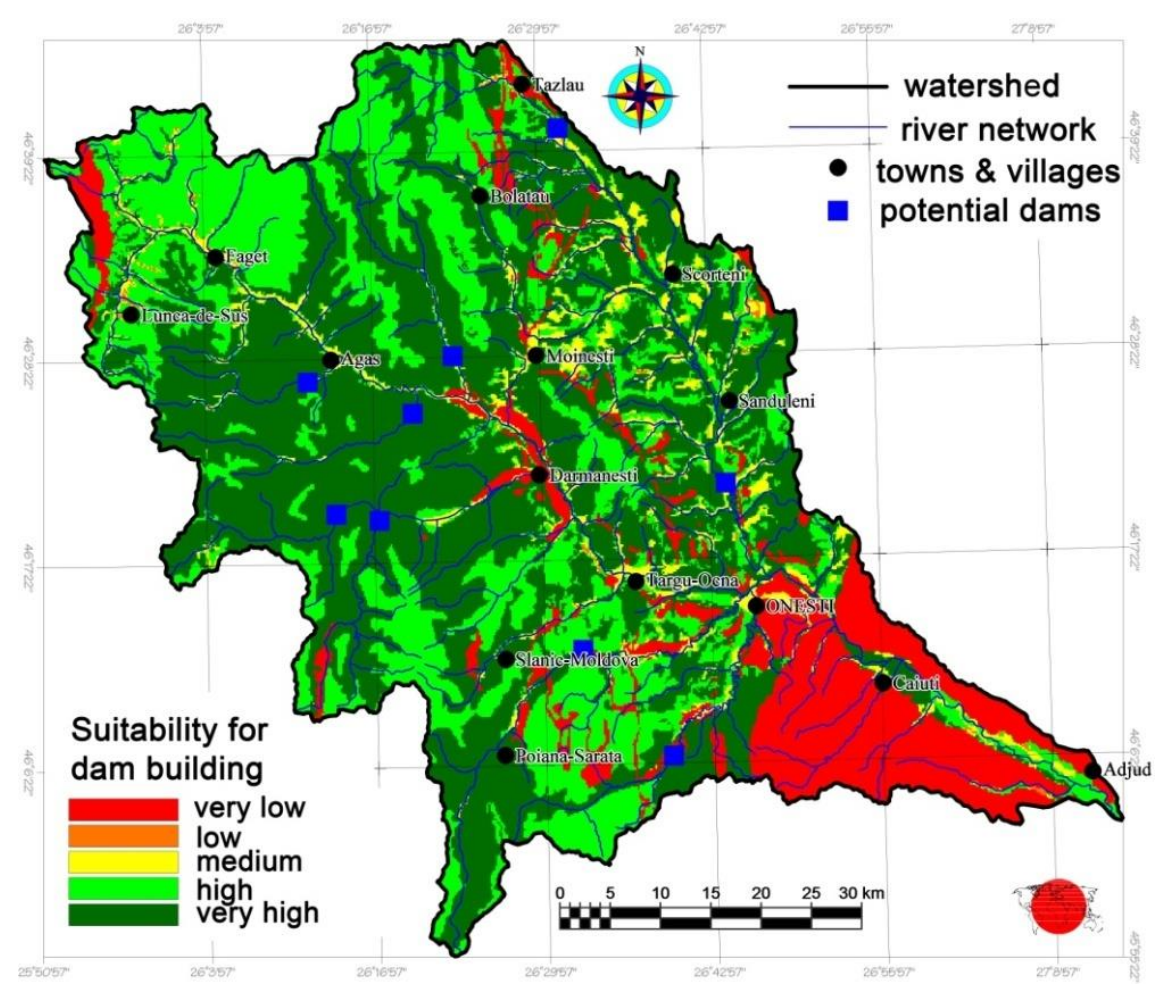

Figure 4. Dam building suitability map for Trotus river basin

A great disadvantage associated with the aforementioned tributaries is the great uncertainty of the water flow rates and the relative isolation from the areas where there is an actual demand for water. There are areas outside of the Carpathian range which were identified to have positive potential. Two of these are located on the Tazlau river and a third one on the Casin River. The flow of the rivers varies, in the case of Tazlau river, near its source having an annual average of approximately $1.6 \mathrm{~m}^{3} / \mathrm{s}$, reaching a value of $6 \mathrm{~m}^{3} / \mathrm{s}$ at the confluence with the Trotus River. The main advantage of those areas is the close proximity to the populated areas which have a high water demand. Therefore, the Tazlau river basin was chosen for further analysis.

The resulting reservoir after the blocking of the water course with a $15 \mathrm{~m}$ tall dam would have a surface of $3.62 \mathrm{~km}^{2}$, the whole surface of the watershed of the reservoir being $993.54 \mathrm{~km}^{2}$ (Fig. 5). Considering the average depth of the reservoir at approximately $6.73 \mathrm{~m}$, the total volume would reach approximately 24.4 million cubic meters. Considering that the average multiannual flow is $6.92 \mathrm{~m}^{3} / \mathrm{s}$, the filling time of the dam can be calculated: 24.4 million cubic meters divided by 6.92 cubic meters per second, resulting in 3468208 seconds, which means approximately 40 days (6 weeks). However, this calculation fails to account for a multitude of factors which can influence the flow rate, such as: the seepage rate, the flow variability, the real flow of the filling cycle, anthropic influences, potential periods of drought or abundant rainfall, water evaporation, the effective rainfall reaching the reservoir, and so on. Also, an ecological flow of approximately $30 \%$ from the multi annual flow must be deducted, in order to prevent the disruption of the balance of downstream ecosystems.In this case, the remaining flow would be $4.76 \mathrm{~m}^{3} / \mathrm{s}$, giving a total filling time of 9 weeks. But this figure can increase 
dramatically, considering the climate change and the degradation processes emphasized in the last years.
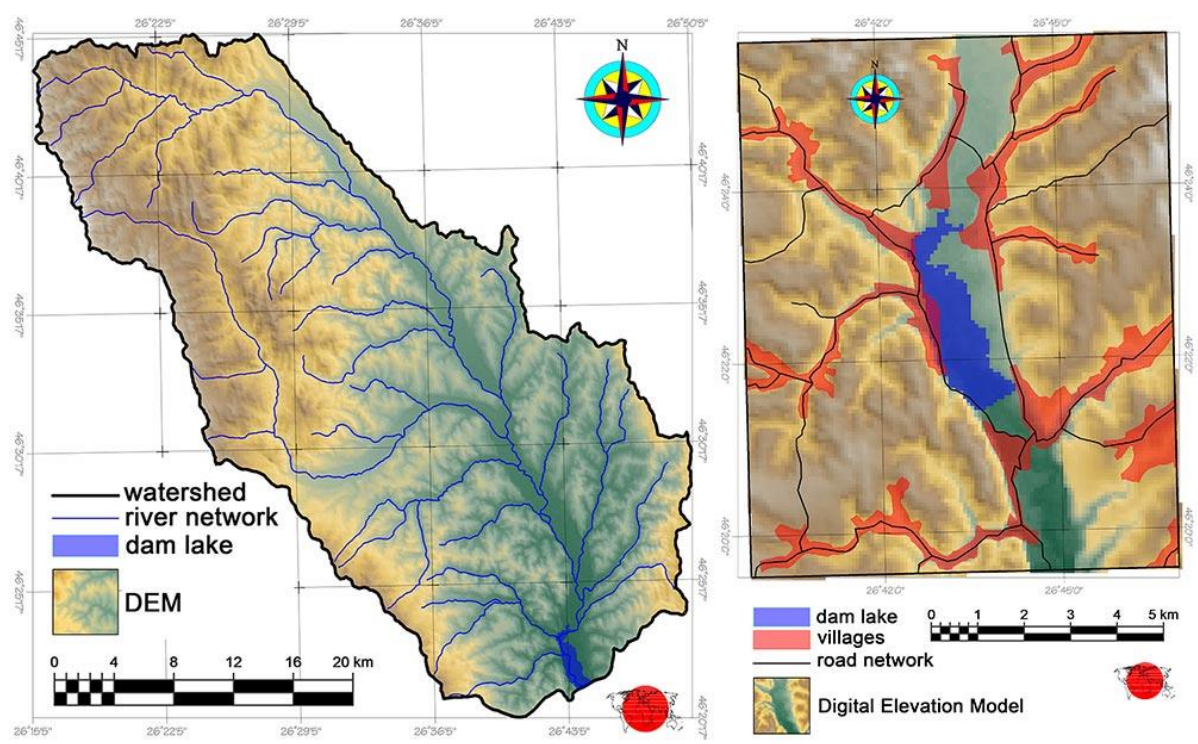

Figure 5. Tazlău case study dam lake and its drainage basin

Considering that the alluvial deposits from the Tazlau basin measured at the Helegiu hydrological station is 5.2tonns/hectare/year, the silting rate of the lacustrine cuvette can be calculated. Therefore, on an annual basis, approximately 516360 tons are eroded from the watershed of the reservoir. The whole volume of the reservoir would be replaced by sediments in approximately 47 years. This value is real only if all the sediments from this perimeter end up in the lake. Therefore this can be considered as the absolute minimum lifespan of the reservoir. Several sediment-regarding issues, for Trotus basins, were previously addressed [5-7].

Rising of the water level in the filling process would create some damage, flooding several sections of communal roads, with a total length of $2.37 \mathrm{~km}$, and a surface of approximately 40 hectares from the residential area of the Scariga and Poiana localities. A Google Earth estimate shows that approximately 200 households from the perimeter of both of the aforementioned localities would require relocation or some form of indemnification. These figures can be considered small, when compared to other hydrotechnical establishments from Romania, where, for instance, in the case of the Izvorul Muntelui reservoir, 2300 households were re-located, affecting a population of 18000 inhabitants. However, these endeavors took place during totalitarian dictatorship. The costs rises to 11 million Euros if we consider the price of one household to be around 50000 Euros, and by a rough estimate, the value of the road sections could cost 1 million Euros.

\section{CONCLUSIONS}

The matter at hand, which was addressed by this paper, is of great significance, considering the numerous implications of the presence of a reservoir in the territory (water reserves for household population use, irrigation, recreation, fish farming and floodcontrol, etc.). In the analysis process, the considered factors are the geology, soils, land use and population. These were assembled into a geoformula, yielding a final 
suitability layer, depicting the suitability for dam construction, which was further reclassified into 4 classes. 9 potential coordinate sets for dam locations were identified, out of which the one located within the lower part of the Tazlau river was selected for further analysis.

A reservoir was simulated, with the following characteristics: a volume of 24.4 million $\mathrm{m}^{3}$, a surface of $3.62 \mathrm{~km}^{2}$ and a $15 \mathrm{~m}$ high dam. The filling times were calculated for different flow rates. Estimations concerning potential compensation costs, or silting time were performed (life span of the reservoir was calculated at an absolute minimum of 47 years). Therefore, the hydrographic basin of the Trotus river, through its well-developed drainage network, has a high potential for hosting hydrotechnical establishments of such nature. Using the water courses in this area is not a novelty, the Poiana Uzului and Belci reservoir being very good examples of such endeavors.

Both the real case of the dam failure from the Belci reservoir (a dezastrous accident, that took place in 1991, after excessive rainfall [8], as well as the present case study, draw attention over the importance of detailed planning prior to deploying a project of such span, the consequences in case of dam failure being catastrophic. An important part of the planning is the identification of the areas which emphasize potential for safe exploitation.

\section{REFERENCES}

[1] Romanescu Gh., The effect of the carastropgic inundations from Siret River's lower basin (Romania) from july 2005 in the context of the global climatic change, 2006, "Riscuri şi catastrofe" Journal, Casa Cărţii de Ştiinţă, Cluj-Napoca, pag.203-216

[2] Chirilă G., Resursele de apă din bazinul râului Trotuş - studiu de hidrologie şi calitatea apelor, PhD Thesis, Universitatea Bucureşti, 2010

[3] Gheorghe D., Dăscăliță D., Considerații privind impactul antropic asupra resurselor de apă subterană din bazinul hidrografic al râului Trotuş, ABA Siret, Bacău, 2004

[4] Unguraș I.A., Populația și așezările umane din bazinul hidrografic al Trotuşului, $\mathrm{PhD}$ Thesis, Universitatea București, 2011

[5] Ichim I., Rădoane M., Câteva aspecte privind aportul albiilor râurilor Doamna (Argeş) şi Trotuş, ca surse de aluviuni, Lucrările Staţiunii de Cercetări "Stejarul”, Piatra Neamţ, Seria Geografie, 1985

[6] Rădoane M., Rădoane N., Dams, sediment sources and reservoir silting in Romania", Geomorphology, Science Direct, 2005

[7] Dumitriu D. Sistemul aluviunilor din bazinul râului Trotuş, Editura Universităţii Suceava, 2007

[8] Enea A., Romanescu G., Stoleriu C. C., Iosub M., Albu M., Evolution of river meandering and sinuosity ratio in Tazlau river basin, Romania, International Symposium "Multidisciplinary Scientific GeoConference" (SGEM) Albena, Bulgaria - Hydrology and Water Resources Section, 2015 